\title{
The Effectiveness of the Conditions of Validity of the Barrier Condition from Disposing of Property as A Restraint
}

\author{
Saleh Nasser Al-Otaibi \\ Associate Professor, Department of Private Law Kuwait International College of Law, Kuwait \\ Corresponding author email: alotaibi@kilaw.edu.kw
}

\begin{abstract}
Private property is protected by almost all laws, there are some exceptions of disposing of one's property, these exceptions are arranged by the law. Kuwaiti constitution pays much concern about the right of ownership. There is no risk when the law determines restrictions on the owner's right to dispose of property, but, the risk occurs when the law permits the will of individuals to dispose of the property. The privative clause of the disposition of the right of ownership is one of the conditions that are contrary to the nature of the contracts that transfer the ownership, rather than lead to the transfer of ownership the study concluded that Kuwaiti law did not confine the occurrence of the barrier to the disposal of a particular type of legal behavior. The motive condition determines the privative clause from the disposition. Flexibility requires a strong motive as a flexible standard that accommodates any situation that arises in the future. The strictness of Kuwaiti law shows that it did not always make the condition inhibiting from disposal permanent, but rather that it must be temporary in a period. The militancy of the Kuwaiti law in considering the militant opinion to narrow the effects incurred on the violation of the privative clause of the disposal.

Keywords---barrier, disposing, property, restraint, validity.
\end{abstract}

\section{Introduction}

The Kuwaiti Constitution stipulates in Article 18 that private property is protected. No one shall be prevented from disposing of his property except within the limits of the law. Not surprisingly, the Constitution pays much concern about the right of ownership, it is the most important right in rem but is the original, from which all other branches of the right are derived, and in which all powers legally granted for a person to benefit for a particular property. Furthermore, the person has the authority to use, exploit, and or dispose of the property. However, exploiting and or disposing of the property is the most important, as he solely owns all the rights in rem who have the full power of disposition and that in itself is the essence of the right of ownership, and for this reason, the owner's authority to dispose of his property is not restricted only by law, which is confirmed by the Kuwaiti constitution. There is no risk when the law directly determines restrictions on the owner's right to dispose of his property (Wallace, 1994). Instead, the risk occurs when the law permits the will of individuals to prevent the owner from disposing of his property $^{1}$, this is known as voluntary restraints individual limitations as approved by the Kuwaiti Civil Code, in article 815. This risk stems from the combination of two contradictions, such as, in the sale contract, how it comes when is ordered that "the buyer should not dispose of the thing sold, so the right of ownership of the buyer is taken. However, to achieve the practical benefit, operational necessities are required to permit people to place a privative clause as long as it does not affect the essence of the property right. Moreover, Because the necessity should not be exaggerated without increasing the limit, the Kuwaiti Civil Code did not leave absolute liberty to the will of individuals to apply the condition inhibiting of disposition ${ }^{2}$, and to be valid it should have three conditions: a) limiting its adverse effects, b) narrowing its scope, and c) taking advantage of it to the fullest extent possible

\footnotetext{
${ }^{1}$ Wallace, James (1994). The dilemma of the disposition of troubled FHA-insured multifamily rental property.p(5),

${ }^{2}$ Qadada, Khalid. Ahmed ., The Precise in Explaining the Palestinian Civil Law, Original Real Rights, $1^{\text {st }}$ ed, 1997, p 6.
} 
(Qadada, 1997). One may ask, did the law succeed in that? The answer to this question is divided into three topics, in which the researcher will examine these three conditions. The researcher also scrutinizes its effects which makes it an obligation to take the narrow interpretations of such effects. These are the following topics that the researcher will deal with.

The first topic: legal disposition when transferring the property.

The second topic is based on a strong motive.

The third topic is to be temporary, with a reasonable duration.

The Fourth topic Narrow interpretation of the effects of a non-disposition condition Note: If the term law is mentioned without allocation, then it means the Kuwaiti Civil Law No. 67 of 1980.

\section{The first topic: legal disposition when transferring the property}

According to Article 815 of the Civil Code, the privative clause, the disposal of disposition must be mentioned in the same legal disposition to which the recipient has acquired ownership of certain money ${ }^{3}$. his condition consists of two parts:

The first part: the condition that inhibiting the disposition should be provided as a clause in legal disposition.

The second part: this legal action is a transfer of ownership.

The first requirement - the condition inhibiting the disposition should be provided in legal disposition:

Since the right of ownership is one of the original rights in rem, then its acquisition is in one of two ways; legal disposal or legal fact (Ferris, 2008). The difference between them is the role played by the will of the person; legal disposal is voluntary sources of commitment, whereas the legal facts are involuntary sources of commitment ${ }^{4}$.

In this case, the will exists in a certain way to have a legal effect, such as the acquisition of ownership of a particular property, which requires the availability of certain conditions (Testa \& West, 2010). Such as the attainment of eligibility and its freedom from defects of the will ${ }^{5}$. As for involuntary sources, they are facts on which the law has a specific legal effect, regardless of the role of the will in its creation if any, it has no consideration except in terms of being a reason for arranging the legal effect (Kaleta, 2018). Then the will is seen as a material fact that has legal bases in the views of the law, and therefore, it is called legal fact.

What matters in this regard is the legal disposal where the will has a significant role in establishing the disposal, and therefore it is called voluntary sources of commitment. The concept of "will" means the will of a person, that is his intention to make a specific decision. In this sense, it is a psychological phenomenon that can be achieved within its owner before it appears to the outside world by expressing it (Mansour, 1991). The law arranges the will to dispose of a particular legal effect, i.e. the law converts what someone wants into a mandatory order if he meets the conditions that make them worthy of respect. ${ }^{6}$

The reason why the law respects the will is that every legal disposition reveals a debt relationship between two or more parties, one creditor and the other is a debtor. Someone should not decide on his own to prevent the disposition of his own money, his decline, in this case, is not legal disposal. However, he aims to circumvent the law, it removes money from the general guarantee to the creditors, because the privative clause leads to the inadmissibility of execution on the money that is not allowed to be disposed of (Al-Badrawi, 1956). Thus, this money is out of the general guarantee of creditors. Therefore, the general guarantee loses its benefit. ${ }^{7}$

Legal disposals are not limited to contracts, but applies to an individual will too where the debt relationship is realized, i.e. the existence of both the creditor and the debtor. However, due to its seriousness in terms of the absence of agreement in emergence, the debtor is solely earning the obligation, and the creditor appears later, it was allowed by the law to be a general source of the obligation's origin. In this case, the agreement between the two parties guarantees that the law will not be defrauded, so each party in the contract will defend its interest that may conflict

3 Kaleta Pawel (2018). Legal Requirements for Pious Dispositions of Will According to the 1983 Code of Canon Law. Roczniki Nauk Prawnych, 28(3EV), p (201-219).

${ }^{4}$ Ferris. C, The Search for Due Process in Civil Commitment Hearings: How Procedural Realities Have Altered Substantive Standards, 61 Vanderbilt $\quad$ Law Review 959

Available at: https://scholarship.law.vanderbilt.edu/vlr/vol61/iss3/4

5 Testa, Megan, \& West, Sara (2010). Civil Commitment in the United States. Psychiatry (Edgmont), 7(10), 30. \& Qadada, Khalid Ahmed ( 2004). The Extent of the Legality of Voluntary Restrictions on the Right to Property: A comparative study of French, Egyptian and Jordanian civil law, Journal of the Islamic University (Humanities Series) 12 - (2), pp: 151-151,

${ }^{6}$ Mansour, Mostafa Mansour, The Role of Will in Forming Legal Behaviour, Egypt, Ain Shams University, 1991, p. 13.

7 Abdel-Moneim, Al-Badrawi, Indigenous Rights in Kind, The Arab Book House, Egypt, $2^{\text {nd }}$ ed., 1956, p. 88. 
with the interests of the other party. As for the sole will and its independence in creating the obligation, there may be a fraud, and the sole will is only a limited source for the establishment of the obligation, and this is provisioned legally. For this reason, the Kuwaiti Civil Code is limited to the promise of the award to the public, in addition to the commandment of independent law. It also includes any sole will which the law permits in the future and from which an obligation may arise.

However, the expansion of the Kuwaiti law regarding the occurrence of the condition that precludes the disposal of the sole will - because it was not limited to the will — included any legal behavior that was carried out along with the sole will ${ }^{8}$. When comparing it with France, Egypt, Palestine, and the United Arab Emirates, in these countries, it was restricted to the commandment without legal disposal caused by the will of the individual (Mufeed, 2016). However, the expansion in their contracts did not specify a particular type of contract like it did by Kuwaiti law as will be seen in the following requirement.

\section{The second requirement - the legal behavior must be a transfer of ownership:}

As a complement to the narrowing of the scope of the stipulation precluding the act, Kuwaiti law did not suffice to stipulate the condition in any legal behavior (Qadada, 2004). It did not take the course of the Egyptian and the UAE laws, which demands the conditioned inhibitor of the disposition of any contract without restricting a certain type of contracts, which opened the door wide for the privative clause for disposition because the contract is a general source of origin of the obligation? .

As for the Kuwaiti law, it required the legal disposition to be a contract or a separate will or to be a transfer of ownership and return the privative clause the disposal of the same legal disposal when the party received the ownership (Ruhuddin, 2013). Whether it is a donation contract, for example, a gift, a netting contract, selling, or a will, or even a promise to a prize to the public. ${ }^{10}$

Both, the operational necessities which created the privative clause to dispose of as a restriction, and its source is the will for the right to ownership, are evident in donation contracts, its applications abound in practice. For example, the donor must stipulate that the gifted person should not dispose of his gift until he reaches a certain age where he becomes capable of protecting making the right decisions. Or because there is a possibility that the donor might withdraw his gift and come up with an excuse that permits him to do so to recover the gifted money, but this type is considered as a donation too.

The donor's position in the gift and will contracts is strong enough to allow him to impose his conditions on the receiving party ${ }^{11}$. He can even prevent the receiving party from enjoying the gift freely (Kruthika, 2018). In this case, the receiving party has no choice but to accept those conditions as he fears that the donor will refrain from going ahead with the donation. This is what made the French ${ }^{12}$ and the Palestinian laws ${ }^{13}$ restrict the scope of their clause to the gift and will only (Al-Haq, 2018). This restriction led to minimizing the benefit that may be derived from the privative clause to satisfy the people's interests ${ }^{14}$.

The researcher believes that the direction of Kuwaiti law is better, as it allowed the introduction of contracts for the transfer of ownership, such as the sale contract, if necessary for operational necessities ${ }^{15}$ in which the privative clause can act, but why are they excluded? Because there are many implementations under the condition that prevented the disposal of sales contracts concluded by the state for citizens in need of housing, so selling them the land at a reduced price commensurate with their financial capabilities to establish private housing for them and their

\footnotetext{
8 Mufeed, Ahmed (2016). A comparative study of The constitutional judgments regarding the protection of Basic social and economic rights in The Arab region, The yearbook of the arab Association of constitutional Law p.199.. https://www.idea.int/sites/default/files/publications/201706-30-annual-book-acl-AR.pdf

9 See Qadada, Khalid . Ah,med supra note 2 cite p. 7

${ }^{10}$ Muhammad, Ahmad Ruhuddin, privative clause of disposal . Master Thesis, Kuwait University, 2013 , p. 53.

${ }^{11}$ kruthika Rao, Gift As Under the Transfer of Property disposition and Mohemmedan Law, 2018, para 11

12 Article 900 of the French Civil Code stipulates that the provisions stipulating that it is not permissible to dispose of gifted or recommended money are valid only if it is temporary and is sponsored by legitimate interests. Even in this case, the judiciary may grant the talented person or his guardian permission to dispose of the money if the interest that used to justify the mentioned item is removed or if it occurs that a more important interest requires that; See this in the French Civil Law, edition of Saint Joseph University in Lebanon, p. 904.

${ }^{13}$ Enas, Muhammad Gad Al-Haq, The privative clause of dispostion, Centre for Arab Studies for Publishing and Distribution, ${ }^{\text {st }}$ ed., 2018, p. 133.

${ }^{14}$ For example, the seller shall not be able , under the French and Palestinian laws to have the benefit of the privative clause of disposing in order to include it in the selling contract, which is of the Compensations contracts, condition to prevent the buyer from disposing of the sold object till the full payment of the price, thus he has no option but to place a condition to maintain the property, but in most cases the Buyer refuses such condition due to his desire to have the property passed to him which can be achieved by the privative clause.

${ }^{15}$ Intended to achieve practical necessities strong motivation which is the second condition of the conditions of validity inhibitor of the dispostion, which is dedicated to him the second topic.
} 
families to settle in, and sometimes requiring them in the sales contract not to have ownership of the property for a limited period so that they do not rush to sell. ${ }^{16}$

Besides, in the sale and purchase agreement, the seller of the house may stipulate that the buyer cannot sell or transfer the house's ownership to a new buyer for a certain period to avoid having to deal with the new buyer that the purchaser wants to sell to.

It is easy to apply the privative clause of disposition to others, ${ }^{17}$ as it applies to confront him from the day of his month in the real estate registry. (Article 2/817 Civil Law), but if the subject of the contract is transferred object, the barrier to disposal will lose its value, therefore Article 817/1 of the Civil Code stipulates that there is no authenticity to the privative clause from acting on behalf of the third party unless this third party knew about the condition at the time of the sale or could have known, in this case, then it is not permissible to adhere to the preventive condition in the face of others who possess the transfer due to a valid reason and was in good faith. ${ }^{18}$ That is why the Palestinian law defines the scope of this condition (Shukri, 1998), which precludes the disposal of real estate and excludes the transfer ${ }^{19}$.

The author believes that the stipulation of Kuwaiti law is better because there are movable properties subjected to the registration system. That is why it is excluded when the operational necessity requires its inclusion in the barrier to disposal, and this is easily achieved in car sales as some finance companies require the Traffic Department to include in the car license book the phrase: "this car is purchased in installments". This remark makes it clear to the prospective purchaser that the ownership of this vehicle is subject to finance (ELail, 1984). This is a prohibitive condition for selling cars. ${ }^{20}$ Also, this condition of goodwill not only negates him but also prevents the disposal of the car to others at the same time it applies to those who want to buy the vehicle. ${ }^{21}$

On the other hand, one of the manifestations to narrow the scope of disposition in Kuwaiti law is that it does not apply to contracts that promise to sell or pledge (Sanhour, 1965), because they do not include ownership transfer and they were the subject of a dispute in Egyptian jurists because the Egyptian law did not require that the inclusion of transfer of ownership in the contract. ${ }^{22}$

Concerning the contract to promise to sell, as the one to whom the promise was extended will put a condition on the promisor, not to dispose of the product during the promising period unless he guarantees that he wants to buy something during the promise. Furthermore, the gravity to allow this requirement to hold the promise of selling allows circumventing the law, whereby the owner even temporarily withdraws any amount of money from his creditors by agreeing with anyone that offers him to sell the product but also to agree with him in keeping up the promise to prevent the disposal during the period of the promise. This type of disposition is forbidden to execute because the prohibition from disposing of requires the prevention of execution, and the promising party did not lose ownership of this money.

The same applies in the mortgage contract, where the Kuwaiti law did not approve the condition inhibiting the disposition because the disposal did not transfer the ownership. The Mortgagee creditor places a condition on the mortgagee debtor not to dispose of the mortgaged object until the debt guaranteed by the mortgage is recovered to avoid following the execution measures against the one to whom the property is transferred, which is more complicated than the implementation of measures against the Mortgagor. The risk of allowing such action will become a reasonable condition in mortgage contracts. The mortgagee will become much stronger than the mortgagor, as a result, imposing upon him the condition that leads the mortgage contract to lose the intended aim which is found only to reconcile between the owner's freedom to dispose of the mortgaged subject to enjoy the greatest benefits of ownership, ensuring that the creditor obtains its right through an authority to track the mortgaged

${ }^{16}$ Appeal for Cassation No. 133/82, Commercial, 2/3/1983 Session, a set of legal rules decided by the Court of Cassation, Section I, Volume II, January 1994, p. 667.

${ }^{17}$ A third party, means, a person other than the contracting parties, who set the privative clause the disposal of their contract.

${ }^{18}$ Shukri, Mohamed Sorour, Summary of regulating the right of property in the Kuwaiti Civil Law, $2^{\text {nd }}$ ed., 1998, p. 265.

${ }^{19}$ Therefore, certain Juries say that it is doubtful for the privative clauseof disposal to achieve its aim in the transferred objects because the party subject of the condition may dispose of the transferred object in violation to the privative clause, and he may dispose of the fund from his custody and the rule of custody shall apply . the custody exempts the transferred object from the in kind costs which restrict it as barrier of disposal . see Jaber Mahjoub and others : The right of Title in Kuwaiti law , Kuwait University - 2 2n edition 2012 .p 8

${ }^{20}$ Especially after the Kuwaiti Traffic Law No. 67 of 1976 repealed every condition in the car sale contract that stipulates that the seller retains ownership of the car until it meets the price and that the vehicle license is issued in the name of the buyer. This absolute nullity attachment to the public order, which was confirmed by the Court of Cassation judgment has also stated that traffic law anxious to determine the criminal and civil liabilities arising from the use of motor vehicles - this could be checked at the traffic department to prove the real owner of the vehicleregardless of his breach to purchase the vehicle from its previous owner. See Cassation Appeal No. 1062/2006 Commercial, 12/16/2007 session published in the Judicial and Law Journal, June 2011, Issue 3, Part 3, p. 304.

${ }^{21}$ ELail, Sale in Instalments and Other Credit Sales, Kuwait University, 1984, p. 259.

${ }^{22}$ Abdul Razak, Sanhouri, Mediator to Explain The Law of Civil Law 1; Part VIII, The Right of Property, Plant Knowledge, Alexandria, 2004, p. 444; See also Mansour, Mustafa Mansour: The Right of Property in The Egyptian Civil Code, Abdullah Wahba Library, 1965, p. 102. 
subject and impose an execution on it wherever it is ahead of the ordinary debtors. This is confirmed by the Court of Cassation in Kuwait when the government Credit Bank used to insert the condition inhibiting the disposition of the loan contract, which is given to citizens to build or renovate their homes and then mortgage the house to ensure repayment of the loan amount. However, the court overturned a requirement inhibitor of the act ever been in a contract mortgage that is Non-transferable contract. This represents a narrowing of the scope of application of the precautionary condition to preserve the essence of the ownership right, which is the possibility for the owner to dispose of his property, the bank as revealed by the Court of Cassation that bank has the necessary means to preserve his money and recover the value of the loan through a mortgage contract achieved through tracking and progress as stated above. ${ }^{23}$

\section{The second topic: the condition that prevents disposition should be based on a strong motive}

This condition is very important, as it is the basis of the determination of the condition that precludes the disposal, it represents the operational necessities, and therefore it is stipulated in most countries that have taken the condition to prevents the disposition, because the fundamental right of ownership is the freedom of the owner to dispose of his property, and that allowing departures from this origin restricts the property must have a strong motive to be justified, to explain this condition, two requirements must exist (Pateman, 2002). First, the author will explain the meaning of a strong motive, and then the types of interests which represent a strong motive $\mathrm{e}^{24}$.

\section{The first requirement - the meaning of strong motive}

Article 815 of the Civil Code stipulates that the condition that prevents the disposition of property shall not be valid unless it is based on a strong reason or motive, so first, it is essential to define what is meant by the motive, and then the researcher explains the criterion by which its strength is measured.

\section{The meaning of the motive}

Every clause in a contract becomes an obligation after the contract has been concluded, and there is often a motive in the contractor's mind that leads him to adhere to. This motive is called the motivator, and accordingly, consent is given to the contract. One must not confuse it with the cause of the obligation, which is a cornerstone of the contract that cannot be performed without it. Article 176 of the Civil Code in its first paragraph states that every obligation must have a legitimate cause. Otherwise, the contract is void. As for the motive, it may be present and overshadow the contract, and it may not have any effect on the contract, whether it was present in the contractor's mind or not at the time of executing the contract.

Therefore, Article 176 of the Civil Code stipulates in its second paragraph that the reason for the motivated motive that pushed the contractor to make the contract if the other contractor knew about it, or he should have known. Thus, from Article 176 mentioned above, the motive falls within the concept of cause, that is: it becomes part of it - if the other contractor knew the motive or s/he should have known about it. The reason is defined as the direct goal that the contractor seeks to achieve in return for his/her consent to assume the obligation, and its objective does not differ from person to person. For example, in the sales contract, the reason for the seller's commitment is to secure the price, and the reason for the buyer's commitment is to receive the sold object. These are the main reasons for any sale contract. As for the motive, it is the indirect goal that the debtor seeks to achieve the cause.

If the reason for the seller's commitment is to secure the price, the motivator may be to spend the price in paying for the house or to pay for medical expenses or other factors that differ from one contractor to another. ${ }^{25}$ Because the motive is a personal matter that varies from person to person, it is difficult to verify. Therefore, Article 177 of the Civil Code stipulates that the motive should not be considered unless the other contractor knows about it or should have known, and in this case, it must be legitimate.

However, if someone wants to apply the above to the preventive condition of the act, then the reason does not change, and that is the thing does not come out of the ownership of the stipulated condition (Mustafa, 1984). As for

\footnotetext{
${ }^{23}$ See, Challenge In Cassation No. $3 \backslash 2018$ General Authority, session $26 \backslash 3 \backslash 2018$, published in the Journal of the Judiciary and Law, 42, Part 3, March 2019, p. 14; See also, The Commentary on The Judgment Hussein Al-Rashidi and Anwar Al-Fezia in their research "The extent of the permissibility of disposing of the mortgaged real estate of the Kuwait Credit Bank", a research published in the Journal of Law No. 4, 43, December 2019, Kuwait University, p. 13.

${ }^{24}$ Pateman, Carole. "Self-ownership and property in the person: Democratization and a tale of two concepts." Journal of Political Philosophy 10.1 (2002): p.24.

${ }^{25}$ See note 5, p. 140.
} 
the motive, it differs from one case to another, and to identify it; one should answer the following question, why does the conditioner not want this thing to come out of the ownership? Often the motive for the condition preventing the disposal is to protect a specific interest for that reason the stipulator stipulated the condition to prevent the disposal. ${ }^{26}$ Therefore, the explanatory memorandum of the civil law has a similar meaning between the interest and the motive. ${ }^{27}$

Moreover, since the motive is included in the concept of the cause, then Article 177 of the Civil Code, which assumes that the obligation has a legitimate reason, even if it is not mentioned in the contract until the evidence is established to the contrary, that is: it assumes that the preventive condition of the act is a legitimate motive and that the interest which is protected as legitimate as well, and this is a simple legal presumption that the stipulated person has to prove, otherwise, so if he succeeded then the condition shall be null and he becomes free to dispose of the property. ${ }^{28}$ However, it is not enough for the motive to be legitimate; rather, it must be strong (Ahmed, 2004).

\section{The standard of motive power}

The requirement to be strong for the condition preventing the disposal means that there should be no regard for any motive, even if it is legitimate but rather the purpose for which the conditioner seeks to achieve is of great importance, that is: it represents a serious interest that justifies the requirement of the condition which stipulates the disposal by disrupting the most important authority of the owner to his property, which is the authority to dispose of. Therefore, the term strong is a cause and not a mere whim or caprice sought stipulated behind the condition of the inhibitor act still not enough even though legitimate.

Thus, the serious interest is evidence and a criterion on the availability of the strong motive for the conditioner, which prompted him to stipulate the condition preventing the disposition to the extent that the law may permit the privative clause of disposal as a restriction on the property, contrary to the original, which is the freedom of the owner to dispose of one's property. . The judge shall assess the seriousness of the intended interest according to the circumstances of each case presented, and that by comparing between the intended interest and the corresponding interest of allowing the disposition of the property, if the primary interest is greater than the second, then the motive on condition inhibitor of disposition is strong, so it is right (ELail, 2009). However, if the second interest is stronger than the first and outweighs its importance, the motive's strength will be weakened, and the condition preventing the disposition will be null. ${ }^{29}$

An important question arises about what if the circumstances change and the serious interest on which the strong motivator at the time of the contract remains, shall the privative clause of disposing of becoming null after it was true?. As an example, if the house which the Conditioner placed a condition not to be sold, became not fit for lodging, so is it possible to the buyer, if the conditioner didn't permit, to sell the house and buy a new one, to resort to the Judge asking for permission, i.e. here s/he is asking to replace the house which is prevented to dispose of with another ${ }^{30}$

Kuwaiti law did not regulate this issue, so some jurists ${ }^{31}$ reported that the stipulator may ask the judge to authorize him to dispose of the ownership and the judge may authorize him if he verifies that the serious interest has ceased to exist. The researcher supports the other opinion, ${ }^{32}$ which states that it is not permissible for the judge without a legal provision to give him this power, because it is a deviation from the binding force of the contract and the encroachment on the will of the conditioner who, if he knew from the outset that the prevention condition that he placed may be subjected to a cancellation he would not have entered into a contract. ${ }^{33}$

Finally, as long as the conditioned party has agreed on the privative clause of the disposal and assumed that this condition is based on a strong motive until the condition stipulates that the opposite is true. Then the condition is

\footnotetext{
${ }^{26}$ Abu Zaid Abdul Baki Mustafa: A Study on The Terms of Prevention Act, Kuwaiti Lawyer Magazine, January 1984, p. 54.

${ }^{27}$ See, explanatory note in civil law of Kuwait, Management edition Fatwa and Legislation, 2004, p. 592.

${ }^{28}$ Ibrahim, Sayed Ahmed, Condition Inhibitor of The Act, $1^{\text {st }}$ ed., 2004, para. 106.

${ }^{29}$ ELail, The Right of Property, The Council of Scientific Publications, Kuwait University, 2009, p. 209.

30 The Kuwaiti law permits, instead of placing the condition which prevents the disposal, that the conditioner may put a condition to restrict the disposal in certain manner, but it is not an absolute restriction of disposal, but he may act to buy an object as a replacement .

${ }^{31}$ Ibid. p. 211.

${ }^{32}$ Shukri, Mohamed Sorour, 1998, p. 269.

${ }^{33}$ See, above Article 900 of the Civil Code French.
} 
void alone, and the contract continues to be valid unless the condition is the motive for the contract, then the contract is entirely void. ${ }^{34}$

\section{The second requirement - the types of interests that are a strong motivator:}

The strong motive with the interest it represents without allocating to the type of interest leads to that interest may be material or moral ${ }^{35}$, no difference in that as long as it is of great importance to form a strong motive, which is achieved in three forms according to the beneficiary. The beneficiary of the condition may be the conditioner, the stipulator, or even others. Noting that most of the applications in which the interest is moral for the stipulator, especially when the stipulation is material for the stipend or others, the stipulator in these two cases do not get a material compensation, instead, it is moral, and that is due to his interest in the stipulator or others. Otherwise, he was not keen to stipulate the condition of the disposition. This will be explained in the next three sections:

\section{The first section - the situation in which the privative clause of disposal is in the interest of the stipulator:}

Often the conditioner is the only beneficiary of the condition that precludes the disposal, which motivated to place the condition in legal disposal. The seller may reserve for himself the right to live in his house, which he sold until he finds another house to live in, and the buyer is required not to sell the house to others within a specified period. This is a material interest for the conditioner, so the seller may not find suitable housing after a specific time allowed has passed, and the new buyer may refuse to allow him to stay at home or he may annoy him if the buyer allows him to stay. Another example is if someone gave his son real estate and stipulated that he should pay a monthly rental for living in it, and he is required not to sell the property to guarantee a monthly rental. Or that it is in the interest of the donor to be cautious of the possibility of some excuses that allow him to revoke the contract and thus recover the rented property because the rental income is considered here as a barrier to dispose of his property. ${ }^{36}$ If the previous examples represent a material interest of the conditioner, the new examples of the moral interest are what was presented to the French courts where the French Court of Cassation ruled in a judgment concerning a commandment issued by the parents to their only daughter to give her the family Jewellery. The Commandment included a clause that prevented her from disposing of it. After the death of the parents, the daughter was subjected to economic difficulties that led to the bank's seizure of this jewelry, but the court refused this based on the condition prohibiting the disposition as mentioned in the commandment. ${ }^{37}$

\section{The second section - the case in which the privative clause of the disposal is in the interest of the stipulated party:}

The traditional example of this case is that the donor or the testator must assure the gifted person or the legatee, not to dispose of the money to protect him from his acts due to his wastefulness and indiscretion or lack of experience. ${ }^{38}$ The Conditioner may not prevent the stipulated from the disposal, but he may require a commutation of money, so if he sold the property, he must buy another real estate and the other real estate shall remain under this condition ${ }^{39}$. The condition, in this case, combines between achieving the interest of the gifted money by not losing the gifted money and his freedom to dispose of it, as he may see a better property and sell the gifted property to buy the new one, so the condition preventing it from disposition shall pass to it. ${ }^{40}$

\footnotetext{
${ }^{34}$ Article 190 of the Kuwaiti Civil Code stipulates that if a part of the contract is nullified, the nullity is limited to him alone, without the remainder of the contract, unless one of the contractors proves that he was not concluding the contract other than the null part, then the whole contract is null.

${ }^{35}$ Previously, the matter that the interest should be materialwhich has been argued but not only as moral interest because the material interest is of great importance which justifies the deviation from the general origin in the freedom of the owner to dispose of his property, but the moral interest doesn't justify such deviation, also the moral interest is difficult to define or measure its importance thus it will be difficult for the Judge to verify it. But such view may be challenged with the new trend which doesn't differentiate between the material and moral interest, it is not true that all cases of the moral interest are meaningless or not feasible, to the contrary, most of the moral interests are of great importance and may exceed the material interest . see Abdul Baqi Mustafa, ibid -page 55

${ }^{36}$ This example is mentioned in the explanatory memorandum of Kuwaiti civil law, p. 289.

${ }^{37} \mathrm{C}$ ass.civ 6 Mars $2013 \mathrm{~N}^{\circ} 12-13340$.

${ }^{38}$ See: Abu Zaid Abdul Baki: op. Cit, . P57 . .

${ }^{39}$ Idris,, Provisions of surrender and arrest and their effects in contracts In Islamic law, unpublished Doctoral theses 2009 , p 14.

${ }^{40}$ See: Abdul Razak Sanhouri: op. Cit, . P447 . .
} 
The third section - the situation in which the privative clause of the disposal of interest is in the interest of others: An example of this is the conditioner grants a property and obliges the gifted person to pay a monthly salary to his wife, and he is required at the same time not to dispose of the granted property to ensure that his wife receives the monthly salary. The interest, in this case, is in the condition that if the gifted person refuses to implement his commitment to the other person (the husband whose monthly salary has been confirmed for his wife) may implement his right on the gifted property. ${ }^{41}$

\section{The third topic: that the privative clause of the disposal is temporary at a reasonable time:}

It is not sufficient for the condition to prevent disposition to be contained in the ownership transfer contract based on a strong motive. Instead, it is required that it must be temporary for a certain period suggested by the law to be reasonable, and the reason for this is, the permanent prevention leads to circulation, this is contrary to public order, and it is not permissible except in the text of the law, as is the case in the endowment funds. ${ }^{42}$ Stripping the owner from permanently disposing of his property represents an infringement on the most important authority determined by law, which is the authority to act, and locked up the money for trading thus its value shall be wasted which is detrimental to the public economic order. Therefore, the ban of disposal should be restricted at a reasonable time to achieve the goal of the privative clause. ${ }^{43}$

Given the correlation of the condition which restricts the disposition with its intended aim, and its difference from a case to another it would be appropriate that the period shall be determined according to a standard characterized by the flexibility to allow the judge to estimate based on the circumstances of each case, whether the prohibition clause of the act that has been identified for the period exceeding the goal of its enforcement or not. This is what Kuwaiti law has implemented. it referred the judge to a flexible criterion as "reasonable time", this general standard is better than the arithmetic standard of specifying a period, not beyond the requirement of preventing the disposal. ${ }^{44}$

The accounting period can be in the circumstances of a particular case for a very long period that exceeds the goal of preventing the disposal, ${ }^{45}$ the prohibition from disposing under a certain period may be in the ruling on permanent prohibition in terms of impact, although it is temporary for a certain period, and this is achieved if the period is significantly prolonged, or it is stipulated for the life of the stipulated person. Some jurists see that 46 "there is nothing to prevent the reasonable period from being the life of the contingent, the stipulated or others". The prohibition may be extended throughout the life of the person prohibited the disposal, and it is nonetheless temporary for a reasonable period. For example, the conditional must stipulate a monthly salary for himself throughout his life. For preventing disposal, it may take the life of the prevented disposal and be a reasonable time, for example, someone gives a real estate to another, known as profligate, and required him not to dispose the property throughout his life, if the gifted person died, the real estate should pass to his heirs without the restriction of the condition prohibiting the disposal.

The period of preventing the disposal may extend to the life of others and be a reasonable time, for example, the grantor of a real estate may make a condition on the gifted person a monthly salary to be given to a third party during the life of this person, if that person died before the death of the third person, the real estate shall pass to the heirs of the gifted person with the condition of prohibiting the disposal and the heirs cannot dispose the real estate throughout the life of others until the donor guarantees the continued monthly payment.

Accordingly, the period is reasonable if it does not exceed the objective of the prevention of disposal. For example, the period is reasonable in the contract for sale in installments if the period for preventing the disposal is the period of paying the installments. Conversely, the duration of the prevention of disposal is unreasonable if it exceeds the period of payment of the premiums, in that case, the condition preventing the disposal is exceeded the reasonable period, which is the period of payment of the premiums, to achieve the goal of the condition of the prevention of disposal mentioned in Article 190 of the Civil Code, and the contract remains valid unless the privative clause the disposition is the motivation for the contract then the contract will be completely voided. ${ }^{47}$ Some

${ }^{41}$ Abdul Khaleq, Hassan Ahmad, The Right to Ownership, Dubai Police Academy, 1' ${ }^{\text {st }}$, ed., 1990, p. 68.

${ }^{42}$ Abdul Razak Sanhouri, Civil Law Part 8, p. 449.

${ }^{43}$ Antr, Ali Jaber, Restricted: The Right of Ownership in Kuwaiti Law, $3^{\text {rd }}, 2012$, p. 89.

${ }^{44}$ This is the disposition of the Palestinian civil law, where not only the standard of a reasonable period was mentioned in Article 947 but also exercised the third paragraph of the said article where the reasonable 15 years may not be exceeded, based on the discretion of the judge. See, Enas, Muhammad Gad Al-Haqq: p. 174.

${ }^{45}$ Jaber, Mahjoub, Property, p. 89.

${ }^{46}$ Ibrahim, Abu ELai, The Right of Property, p. 213.

${ }^{47}$ Ibid. p. 214. 
jurists contradict these views. ${ }^{48}$ Article 190 of the Civil Code states that if the period is unreasonable, the entire condition becomes null and void, and then the contract shall be reviewed, if the privative clause is the motive for the contract, the contract becomes null also. However, if it is not, then the contract remains valid. This opinion adds that it is not permissible to measure the period in this case over the period in other cases and apply the theory of reducing the contract. Both cases are different. For example, the standard period of staying is five years as defined by the law, and if the contract exceeds that, the judge will apply the theory of reducing the contract and the period stays five years as defined by the law where it is not permissible to prolong it. As for the condition precluding the disposition, the law did not specify a maximum reasonable period for the judge to adhere to. Therefore, the appropriate solution is for the judge to annul the condition that prevents the disposition and not lessen it with a specific period that was not stipulated by the law. Assuming that the conditioner was satisfied at the time of concluding the contract if he knew the nullity of the condition, then this did not happen, and he did not imagine his presence in the mind of the conditional contractor and gave the judge a power that the law did not provide.

\section{The Fourth topic: the narrow interoperation for the Effects of the privative clause of Disposal.}

Whereas the privative clause of disposal is an exception from the original in the freedom of the owner to dispose of his property, it will not be enough to define three conditions for the validity of the condition, but the researcher narrows the interpreting of its effects ${ }^{49}$ so that the title right shall not lose its most distinctive features, i.e. the freedom of the owner to dispose of the object he owned.

The disposal of privative clause prevents the party subject of the condition to dispose of the object he owns or to restrict his right in disposition in a certain way, also there is a penalty against the violation of the privative clause, the researcher shall set the manner to narrow the effects of the privative clause in the following three requirements :

The First requirement: scope of narrowing the effect of the disposal privative clause:

If the privative clause is provided in general terms which do not allocate certain type of the prohibited acts which caused the party under the condition to be unable to dispose of the property he owns, but what are the prohibited dispositions? do they include all legal acts or certain types only?

Some jurists say ${ }^{50}$ that if the privative clause is expressed in general terms which prevent the owner to dispose of his owned object, in any type of legal dispositions whether against a consideration, as a contract of selling, or without consideration, as the contract of grant or to be provided as a share in the company or to be pledged, also he is prevented to incur anything such as the right of benefit or right of an easement or any other dispositions which may lead to the elapse of the title as whole or to be restricted, because it contradicts with the purpose of the privative clause of disposal, that the title of the property should remain for the owner as a whole.

The opinion also considers that the prevention includes even the material disposal, for example: if the non- to be deposed of is a house, the owner is prohibited to demolish it because the permitting of material works shall cause the privative clause to lose its meaning, and it will not achieve its intended purpose. Normally the purpose of the conditioner- when he grants a house to a third party to lodge in, and place on him a condition not to dispose of it, he permits the gifted person to demolish the house shall forfeit the purpose of the grantor from the privative clause of disposal. ${ }^{51}$

But the researcher supports the other opinion, ${ }^{52}$ to narrow the scope of legal acts which the owner is prevented to take consequences to the intention to explain the privative clause tightly so that the right of title shall not lose its legal sense., therefore the owner is only prevented from the disposition which leads to getting the object out of his property to another person as the selling and grant ${ }^{53}$, also the legal dispositions which achieve such result as a pledge, because pledging the object may end with being subject of legal execution and to be sold in a public auction to settle the debt, then the object shall come out of the custody of the disposed party. also, the person under the condition may act fraudulently against the privative clause by disposing of it indirectly. but the other legal dispositions which shall not cause the object to come out of the custody of the owner such as leasing will remain possible for the owner and he is not prevented from arranging such rights except if they are explicitly stipulated in the privative clause.

Also, the privative clause shall not prevent the passing of the object's title from the owner to another person in nonlegal disposal as inheritance and time, because the property, in such case, passes according to a material fact, and the

\footnotetext{
${ }^{48}$ Abdul Razak, Sanhouri, Civil Law Part 8, p. 451, and Jabber, Mahjoub, Property p. 91.

${ }^{49}$ Abdul Mueim AL-Badrawi :ibid .p. 92

${ }^{50}$ Abdul Razzaq AL-Sanhouri . ibid .page 452, and Mansour Mustafa Mansour : the property right . previous note p.104 , Mohammad Shukri Srour, ibid 272.

${ }^{51}$ Mansour Mustafa Mansour : right of title, ibid . p 92

${ }^{52}$ Abdul Muneim AL-Badrawi. Ibid. p. 96

${ }^{53}$ Al-Hayari, Iman, The concept of property right, edited August 15, 2020, access November 7, 2020, https://mawdoo3.com.
} 
prohibition is limited only to the legal dispositions, also the privative clause shall not prevent the expropriation of the object by the concerned government Authority for the public interest.

Also, the privative clause shall not prevent the owner to give the object in legacy, because the legacy is a legal disposition but after death which, in all cases lead the property to pass to another person ${ }^{54}$, the prohibition is that the object should not get out of the property of the person during his life, also it will not prohibit the owner to practice material dispositions even if they lead to a substantial change in the object, like the demolishing of the house, because the prohibition here is on the legal dispositions, not the material. the law prescribed the penalty of annulment against the act which violates the prohibition and the annulment, as a legal term is related to the legal dispositions only.

\section{The second requirement: The Kuwaiti law permits the restriction of the legal disposition :}

The Kuwaiti law permits another option to the Conditioner instead of barring the disposal due to its risk effect, which is, to restrict the disposal of the owner in the object he owns. the example of these cases is what is known as "the replacement condition", in which the owner may dispose of the object by selling, but he should provide a replacement. the restriction may also restrict the owner not to sell the object except after he proposes it to a certain person, who shall have the priority in buying the objects if he wants to buy it, which is known as the preference or priority right. All such options are meant to avoid resorting to the condition of barring the disposal as long as the restriction achieves the intended purpose, and be of less burden ${ }^{55}$

\section{The third Requirement: avoid exaggeration in applying the penalty against violation of the privative clause.}

If the owner violated the privative clause or the restriction of Disposal, the penalty which achieves the aim of the condition is not to wind up the disposal within which the condition is stipulated, but to annul the act which violates the condition so that the object remains within the custody of the respondent and achieves the aim of the Conditioner of sequestrating the disposal which violated the condition.

To lighten the penalty for violating the privative clause, the law didn't consider the absolute annulment in which, each party of interest may annul the disposal which violates the condition. As a sign of respect to the will of the owner and to allow its effect on the disposal of the owned object even if it involves a violation of the privative clause, the Kuwaiti law restricted the insistence on annulling the act which violates the privative clause on the conditioner who always has the interest to annul the disposal even if the privative clause has been provided to the interest of a third party, because it will be enough for him to insist on the right of annulment if he has a moral interest only, also the request for annulment may be vested in the party to whose interest the privative clause was prescribed if he is a person other than the Conditioner, based on the fact that the privative clause is meant to achieve the interest of a certain person, therefore the said person has the sole right to ask for the annulment of the disposal which violated the privative clause. Also, the said person may waive his right in insisting on the annulment, then the act which violated the condition became valid, and all such matters are meant to avoid the annulment of the owner acts which violated the privative clause, as much as possible as respect to the freedom of the owner to dispose of his property $^{56}$

\section{Conclusion}

There is no doubt in that privative clause of the disposition of the right of ownership is one of the conditions that are contrary to the nature of the contracts that transfer the ownership, rather than lead to the transfer of ownership, it leads them out of the deal, and the duration may be lengthened, which prevents the owner from disposing of, and this is the most important authority, as it distinguishes the right of ownership from other in-kind rights, such as the beneficial right, the right to use and, be equal with it. This leads to withholding funds from circulation, and thus their possessing is accumulated with a small group of people, and ultimately harms the economy due to the use of a specific system in exploiting wealth. Thus, the possessing and the freedom of the owner to dispose of his properties shall preserve the wealth by improving exploitation.

\footnotetext{
${ }^{54}$ Jaber Mahjoub Ali . ibid . p. 94

${ }^{55}$ ELail . ibid .P 220

${ }^{56}$ The explanatory Memorandum of the Kuwaiti Civil Law , ibid. P. 592
} 
Consequently, it was not acceptable at the outset to allow the privative clause from the disposal. However, due to the development of societies, and in response to the legitimate interests of people that result from the privative clause of disposal, some countries have permitted this condition. However, they differed among themselves in terms of its validity, although the predominant trend is to narrow its scope.

Kuwaiti law has established a balance, on the one hand, it stressed the conditions of its validity, and on the other hand, the law decides the benefit of the scope of its application as far as possible, and succeeded in doing so. This was pointed out by dividing the research into three topics. In each topic, the author discussed one of the three conditions required by Kuwaiti law for the validity of the condition that prevents it from taking action. in the Fourth Requirement the researcher discussed the effect of the privative clause, through which he concluded the following results :

First - concerning the condition of precluding the disposal should be provided in the transfer of ownership: 1. Manifestations of flexibility:

Kuwaiti law did not confine the occurrence of the barrier to the disposal of a particular type of legal behavior, as the French law did, which confine it to a contract of gift and commandment. It did not take the course of the laws of Egypt, Palestine, and the UAE which, although launched in contracts but in the field of individual will that restricted the condition in the commandment. In Kuwaiti law the condition which bans the disposition may be provided in any legal action, it will be applicable in any type of contract such as Donations, Compensations, Grant, and in Selling contract where a wide use of it in the housing markets provided by the State to the Citizens at a low price, but added a condition on them not to dispose of the house within a certain period, and this condition has contributed to solving the housing problem.

In addition to its application to the commandment 1 - within the framework of legal actions by the sole will—it can be applied in Kuwaiti law to promise a reward to the public, and other legal acts that arise by the individual will. This is not true in other laws that have narrowed the scope of the restrictive condition to a large extent and did not make it flexible in this area, such as Kuwaiti law, to benefit from.

\section{Manifestations of militancy}

This is evident that the Kuwaiti law stipulates that the privative clause prevents the disposal of legal disposal conveying the ownership should be presented, which led to the exclusion of its application to other non-transferable contracts, such as the promise to sell and the formal mortgage contract, which found scope for implementation in the laws of other countries such as Egypt and the UAE. It has been proven to us that the stipulation of Kuwaiti law is correct because of the adverse effects that resulted from approving it in the promise to sell contract because the promising resorts to it to avoid imposing legal execution against his money by the creditors even though the money did not come from him. As for the mortgage contract, there is no need to include it because the mortgage contract achieved guarantees for a mortgagee creditor who can track the mortgaged property with any owner and impose execution against it to recover his debt from the money ahead of ordinary creditors. Moreover, allowing the inclusion of the conditioned inhibitor of the conduct in the mortgage contract leads to the loss of practical mortgage value because the basic benefit of the mortgage is concentrated in the matter it achieved to mortgagor debtor of the freedom to dispose of the ownership and to enjoy ownership benefits. The condition of banning the Disposal prevents achieving that.

Second - for the strong motive condition:

1. Manifestations of militancy:

This condition is the basis for determining the privative clause from disposition, as it represents a practical necessity that justifies its validity. Where if it were not for the strong motivation, there would not have been a need to determine the preventive condition from disposition, and the other two conditions required for its validity are only to control it and narrow its scope so that it is not misused. The laws in some countries have found it strayed in the legal motive to justify the introduction of the privative clause, but the legitimate motive is present in any contract. Therefore, Kuwaiti law added to it a specific description, which is the motive should be strong. Indeed, the motivator is not considered if the other contractor did not know him and he was not able to inform him, but in the field of the condition that prevents the disposal, the motive must be known to the other contractor and accept it for the consequent obligation of not to dispose of the property that he owns in the contract. also, the motive should be strong, and for such quality, the privative clause should be strongly stressed because it came in contrary to the original practice which requires only a motive without the necessity of being strong. 


\section{Manifestations of flexibility:}

Flexibility manifests through Kuwaiti law requiring strong motive as a flexible standard that accommodates any situation that arises in the future. The motive represents a specific interest to any person so that the interest may be for the stipulator of the stipulated, or it may be for others. It is not enough to be of any interest, but it should be an important and serious interest, which the law described as strong. The judge assesses the strength of the interest according to the circumstances of each case submitted to it by comparing it with the interest of the owner in disposing of his property. If the first outperforms the second, the motive is strong, but if it was less important, then the motive was not strong.

\section{Third - A reasonable term condition:}

The strictness of Kuwaiti law shows that it did not always make the condition inhibiting from disposal permanent, but rather that it must be temporary in a period. And that the period should not be too long because of the interest from the condition that precludes the act, meaning that if the duration of the prevention is prolonged and it becomes, concerning the circumstances of a specific case in the rule of permanent prevention, the condition has not been fulfilled. For this reason, Kuwaiti law did not set a maximum period for the prevention as did the Palestinian law, which set it to a maximum of 15 years.

Accordingly, let us say, under the Kuwaiti law, a contract for the sale of a car in installments for five years, if the condition preventing the disposal was for six years, this period was long and therefore an unreasonable period for it to exceed the intended interest behind the privative clause the disposal. Conversely, a 30-year period is a reasonable period in the Kuwaiti law if the barrier to behave is the life of the stipulated person who is known to have wasted his money, while it is an unreasonable period in Palestinian law because it exceeds the maximum period set in the law. Here, the flexibility of Kuwaiti law appears.

\section{Fourth: The Effects of the privative clause}

The militancy of the Kuwaiti law in considering the militant opinion to narrow the effects incurred on the violation of the privative clause of the disposal so that it will include only the legal dispositions which lead to the passing of the property from the stipulated person, but it doesn't include the other acts or the material dispositions, furthermore it decides whether the privative clause shall only restrict the freedom of the owner to dispose of his owned object without preventing or not. Here, the researcher sees the flexibility of the Kuwaiti law in proposing additional solutions that lead to the same purposes meant from the stipulation of the privative clause of disposal. such flexibility of the Kuwaiti law also appears when it didn't automatically annul the act which violates the privative clause but it may be insisted on by the party to whose interest the condition was stipulated, and the latter may permit the violated disposition, then it will become valid, and all that shall express the respect to the owner's Will to dispose of his property.

\section{References}

Ahmed, I., S. (2004). Condition Inhibitor of The Act, $1^{\text {st }}$ ed., , para. 106.

Al-Badrawi, A.-M., (1956). Indigenous Rights in Kind, The Arab Book House, Egypt, $2^{\text {nd }}$ ed..

Al-Haq, Enas, Muhammad Gad. (2018). The privative clause of disposition, Centre for Arab Studies for Publishing and Distribution, $1^{\text {st }}$ ed., p. 133.

Banks, W. A. (2009). The blood-brain barrier in psychoneuroimmunology. Immunology and allergy clinics of North America, 29(2), 223-228. https://doi.org/10.1016/j.iac.2009.02.001

ELail, I.A. ( 1984). Sale in Instalments and Other Credit Sales, Kuwait University, p. 259.

ELail, I.A. (2009). The Right of Property, The Council of Scientific Publications, Kuwait University, , p. 209.

Ferris, C. E. (2008). The search for due process in civil commitment hearings: How procedural realities have altered substantive standards. Vand. L. Rev., 61, 959.

Idris, I.B. A., Provisions of surrender and arrest and their effects in contracts

Kaleta, P. (2018). Legal Requirements for Pious Dispositions of Will According to the 1983 Code of Canon Law. Roczniki Nauk Prawnych, 28(3EV), 201-219.

Kruthika R., (2018). Gift As Under the Transfer of Property disposition and Mohemmedan Law,

Mansour, M. M. (1991). The Role of Will in Forming Legal Behaviour, Egypt, Ain Shams University, p. 13-30.

Mufeed, A. (2016). A comparative study of The constitutional judgments regarding the protection of basic social and economic rights in The Arab region, The yearbook of the arab Association of constitutional Law p.199..

Mustafa. A. Z. A. B. (1984). A Study on The Terms of Prevention Act, Kuwaiti Lawyer Magazine, January. 
Pateman, C. (2002). Self-ownership and property in the person: Democratization and a tale of two concepts. Journal of Political Philosophy, 10(1), 20-53.

Qadada, K. A. ( 2004). The Extent of the Legality of Voluntary Restrictions on the Right to Property: A comparative study of French, Egyptian and Jordanian civil law, Journal of the Islamic University (Humanities Series) 12 - (2), pp: 151-151,

Qadada, K., A. (1997). The Precise in Explaining the Palestinian Civil Law, Original Real Rights, $1^{\text {st }}$ ed. .

Ruhuddin, Mu, A. (2013). privative clause of disposal . Master Thesis, Kuwait University, , p. 53.

Sanhour, A. R. (1965). Mediator to Explain The Law of Civil Law 1; Part VIII, The Right of Property, Plant Knowledge, Alexandria, 2004, p. 444; See also Mansour, Mustafa Mansour: The Right of Property in The Egyptian Civil Code, Abdullah Wahba Library.

Shukri, Mohamed Sorour. (1998). Summary of regulating the right of property in the Kuwaiti Civil Law, $2^{\text {nd }}$ ed., p. 265.

Testa, M., \& West, S. G. (2010). Civil commitment in the United States. Psychiatry (Edgmont), 7(10), 30.

Wallace, J. E. (1994). The dilemma of the disposition of troubled FHA-insured multifamily rental property

Wardle, J., Steptoe, A., Oliver, G., \& Lipsey, Z. (2000). Stress, dietary restraint and food intake. Journal of psychosomatic research, 48(2), 195-202. https://doi.org/10.1016/S0022-3999(00)00076-3 